\title{
THE IMPERIAL CULTURE AND VISUALITY: THE CONSTRUCTION OF THE IMPERIAL IMAGE IN MONUMENTAL SCULPTURE
}

\author{
Iuliia Gudova \\ Mrs., Ural Federal University, Russia, jgudova@mail.ru
}

\begin{abstract}
Imperial culture is a difficult ethnosociocultural phenomenon. Imperial culture exists in the multi-ethnic character of the states when one ethnos assumes the right for domination over other ethnoses and implementation of administrative and managerial functions at all levels of the organization of the state institutional and investment and communication system. Imperial ambitions of such states surely lead to the fact that the dominating social subjects use culture as a way of legitimization and glorification of the imperial power.
\end{abstract}

One of the most important elements of imperial culture is art. Imperial culture used to exploiting art in two of his functions: designing and representation of social reality. Daniela Bleichmar has offered a concept of "a visual epistemology" for the description of the functioning of visual arts in the system of the imperial culture. It is "the way of the knowledge based on visuality, affecting observation and representation". Visual epistemology acts as a part and a prerequisite of imperial system which has a long history of representation in graphic forms of communication for the solution of the administrative purposes. "The visual empire" by Daniela Bleichmar connects natural history, visual culture, and management of the empire. An important element of a visual epistemology is the cultural geography and cultural anthropology which are also created by graphics and picturesque means.

In my opinion, visual practices of the Russian Empire gives for as a lot of striking examples of an imperial images construction. Visual images of the Empire were created by means of engravings, arts, and crafts, theatrical sceneries, posters, sculptures, architectural complexes. By means of these artifacts, residents of the empire could gain an impression about imperial norms, values, characters, ruling elite, about the remote regions of the country. By means of images of region's nature landscapes and home portraits of the empire's residents, the ruling Centre extended the influence on the periphery and consolidated the people of the empire.

In contemporary culture, imperial visuality develops using traditional arts and new media means. Traditional means include sculptural monuments to the most important figures of imperial history - Ivan the Terrible (Moscow), Vladimir the Great (Moscow), Alexander III (Yalta, Crimea) and others. The media for creating an imperial visual anthropology include movies and television series, animated films on subjects from the history of the empire. They give a modern idea of the history of the formation of the empire, its founders, heroes, major historical events and significant dates. Values and norms that regulate the daily life of imperial life are shown on the examples from the life of the heroes of films. In this way, cinematic visuals carry an imperial myth and contribute to its consolidation in the minds of the audience.

On numerous examples in monumental sculpture works, we research how imperial culture designs an imperial image, forms imperial consciousness and then represents them on other territories as within the 
IJASOS- International E-Journal of Advances in Social Sciences, Vol. IV, Issue 10, April 2018

country, and beyond her limits

Keywords: imperial culture, visuality, visual epistemology, the myth of Empire, imperial image, the image of Empire.

\section{INTRODUCTION}

Imperial culture is a difficult ethnosociocultural phenomenon. Imperial culture exists in the multi-ethnic character of the states when one ethnos assumes the right for domination over other ethnoses and implementation of administrative and managerial functions at all levels of the organization of the state institutional and investment and communication system. Imperial ambitions of such states surely lead to the fact that the dominating social subjects use culture as a way of legitimization and glorification of the imperial power

The elite of the empire is the subject of the production of imperial culture: it constructs and represents the culture of the empire on the territory inside and outside this state. Imperial culture through representatives is a way of the ideological influence of the imperial elite on the rest of the population of the empire. The function of the elite is the reproduction and, as a consequence, the dissemination of imperial culture in the non-imperial cultural space of the life of other peoples, including those inhabiting the territory of the empire.

One of the most important elements of imperial culture is art. As T.S.Zlotnikova (Zlotnikova, 2014, 213) and M.N. Shumikhina (Shumikhina, 2017, 130) told Imperial culture used to exploiting art in several functions: visualization of imperial unconscious, designing and representation of social reality.

\section{METHODOLOGY}

Daniela Bleichmar has offered a concept of "a visual epistemology" for the description of the functioning of visual arts in the system of the imperial culture. It is "the way of the knowledge based on visuality, affecting observation and representation" (Bleichmar, 2012, p. 8), "the technique of creating and circulating knowledge" (Bleichmar, 2015, p. 236), "method of creating and disseminating knowledge" (Bleichmar, 2015, p. 236). The visual epistemology acts as a part and a prerequisite of imperial system which has a long history of representation in graphic forms of communication for the solution of the administrative purposes. "The visual empire" by Daniela Bleichmar connects natural history, visual culture, and management of the empire. An important element of a visual epistemology is the cultural geography and cultural anthropology which are also created by graphics and picturesque means.

Other striking examples of the construction of an imperial image were visual practicians of the Russian Empire. Visual images of the empire were created by means of engravings, arts, and crafts, theatrical sceneries, posters, sculptures, architectural complexes, etc. By means of these artifacts, residents of the empire could gain an impression about imperial norms, values, characters, ruling elite, about the remote regions of the country, etc. By means of images of landscapes of the nature of regions and home portraits of residents of the empire, the ruling centre extended the influence on the periphery and consolidated the people of the empire.

An illustrative example of the creation of an "imaginary geography" is given by E.A. Vishlenkova, describing the emergence of an encyclopedia of structured knowledge of Russia and ethnographic descriptions of its peoples, atlases with maps and drawings with views of cities in the XVIII century. The author emphasizes that due to such atlases the state was perceived as a single, unified, interconnected space. Such atlases were created thanks to special expeditions, which included chroniclers and topographers. The author notes an interesting detail: during the expedition, the artists accurately and without additions or distortions sketched the views and sights of different cities. Thanks to these drawings, the inhabitants of the country could see the "Russian Empire and the Russian land". The need for a variety of visual products depicting the types of the empire was explained by the need to "represent the country as a single space," and the idle contemplation of these images was "visual entertainment, which became a kind of factory of meanings for the viewer" (Vishlenkova, 2005, p. 54). E.A. Vishlenkova emphasizes the functional nature of such images: "in itself, this artistic production was a factor in the cultural and visual development of the territory of the empire, the appropriation of new lands through their visual recognition" (Vishlenkova, 2005, p. 56). In the first half of the 18th century, such a visual text was necessary for the glorification of the empire and was a "visual ode to the empire." The image of a large number of cities was to testify to the wealth of the country. Many different structures were to be perceived as the result of creative efforts by the authorities. "As a result of this internal audit, the empire appeared as an aggregate of objects (cities, settlements, buildings, estates) that could be placed by which the authorities could operate" (Vishlenkova, 2005, p. 58). Each emperor changed the name of the cities, arranged symbolic temple signs along this space, traveled along ideologically important routes and changed the administrative map of the country as if he was trying to find the center of 
his empire, he determined the country's place on the political map of the world.

For the emergence of the Russian state cultural policy, changes in the culture in the XVII century, when Russian culture was transformed not simply into the culture of the empire (the Russian Empire), but also into the imperial culture, were important. At this time she began to learn the West European experience: Western achievements were transferred to the Russian reality (Astafyeva, Avanesova, 2015, p. 209). Already in the XIX century, parameters of state regulation of the sphere of culture appeared. Among them was support for the development of the literary national language, the system of primary and vocational education, preservation of the historical heritage. O.N. Astafyeva and G.A. Avanesova conclude that cultural policy has always been aligned with the pragmatic tasks of the empire and has evolved in the light of imperial interests and values.

In contemporary culture, imperial visuality develops using traditional arts and new media means. Traditional means include sculptural monuments to the most important figures of imperial history - Ivan the Terrible (Moscow), Vladimir the Great (Moscow), Alexander III (Yalta, Crimea), general Ermolov (Mineral Waters, 2008), (Pyatigorsk, 2010) (Gushchyan L., Magomedova A., Mahmudova Z., 2014, 131), (Fedulin, Bagdasarjan, 2013, 17), (Shcherbinina, 2015, 47). The media for creating an imperial visual anthropology include movies and television series, animated films on subjects from the history of the empire. They give a modern idea of formation the empire history, its founders, heroes, major historical events and significant dates. Values and norms that regulate the daily life of imperial life are shown on the examples from the life of the heroes of films. In this way, cinematic visuals carry an imperial myth and contribute to its consolidation in the minds of the audience.

\section{RESULTS}

Let's take a closer look at the case with sculptures. Of greatest interest to us are monuments to politicians and the way in which they participate in the design and representation of social reality, in what way they participate in the formation of imperial culture.

N.R. Saenko and A.I. Shipitsin asserts that sculptures are one of the most important tools for constructing political consciousness: "They (sculptures) are ... markers of social and historical memory and perform an important function - accumulate, generate, broadcast certain information" (Saenko, Shipitsin, 2010, p. 80). In their opinion, the popularity or unpopularity of the monument is determined by a combination of factors. The economic and the political aspects are very important in which there is a sculpture. Thanks to this, one monument in different historical moments has a different status, value, and coloring. "The diachrony of memory depends on the state of the means of its translation, on what meanings are currently updated by the monument. In turn, the transformation of the discourse of memory provokes changes in the cultural and semiotic landscape of the city "( Saenko, Shipitsin, 2010, p. 80).

According to the researchers, the cultural memory represented by the sculptures is closely dependent on political ideology. Thus, sculpture changes cultural memory in accordance with a political request. N.R. Saenko and A.I. Shipitsin calls such a policy of cultural and symbolic. In our opinion, it is such a policy that is part of the imperial culture and allows legitimizing the ruling power.

As the authors emphasize, the sculpture differs from other types of fine arts in a three-dimensional image, reality, and activity of perception. Due to these qualities, the authorities use power as a means of propaganda (Saenko, Shipitsin, 2010, p. 82.). Thus, the authors conclude, sculpture, including a monument, is a social phenomenon because the information presented is variable depending on the power.

On the territory of Russia for the past two years, three significant monuments were established: on November 4, 2016, a monument to Prince Vladimir the Great in Moscow, July 26, 2017, a monument to Tsar Ivan IV the Terrible in Moscow, November 18, 2017, a monument to Emperor Alexander III in Yalta.

Thanks to the installation of the monument of a historical personality, the authorities want to update the historical character in the cultural memory of the population. Including through the creation of various historical myths around this character. Through the distribution of monuments, the Center creates a certain cultural memory, through which it can manage the Periphery. The monument to Tsar Ivan IV the Terrible evoked a resonance in Russian society. This historical figure is an ambiguous figure. On the one hand, he significantly increased the territory of the Russian state, on the other hand, during his reign, there were periods of turmoil and oprichnina, in which tens of thousands of people died. Because of disputes in the society about whether to put a monument to Grozny, moved the city of the installation of the monument, the installation site, several times postponed the date of opening the monument.

The monument to Emperor Alexander III, in our opinion, was established for marking Crimean territory with Russian monuments. Yalta is one of the largest cities in the Crimea. After the annexation of the Crimea to 
Russia, a number of measures were taken in the sphere of culture to designate the land as Russian. First, the time zone of the region was changed from Kiev time to Moscow time, the difference was one astronomical hour. Secondly, the official state language was changed from Ukrainian into Russian. And thirdly, the installation of a monument to the Russian emperor in one of the major cities of the Crimea became a logical extension of marking the Crimean territory as Russian. Thanks to this, the Center of the country introduces its culture, transforms the cultural memory of the periphery: Crimea. This helps to strengthen the connection between the center and the ceriphery and legitimize the power of the center in the territory of the periphery.

The most interesting example is the monument to Prince Vladimir the Great. According to history, he baptized the Rus in 988. On November 4, 2016, in the state holiday of the Day of National Unity President Putin V.V. discovered this monument. Sculpture in height reaches 17.5 meters (for comparison, monuments to Ivan the Terrible and Alexander III 2.5 and 4 meters). Sculpture to Vladimir the Great is installed in the very center of Moscow on the guarded territory of the Moscow Kremlin. Visually, Vladimir's height is equal to the towers of the Moscow Kremlin. The towers were built in the 15th century around the Moscow Principality. Then, in the course of history, they were destroyed several times and reconstructed. In the periods of history, when Moscow was the capital of Russia (the Russian state, the USSR, the Russian Federation), the power structures were located on the territory of the Kremlin. Thanks to this, the Kremlin in Russian modern consciousness symbolizes state power: it is there that most of the significant political events take place. Thus, the monument to the Baptist of Russia stands on the background of the symbol of state power. Recently we see in Russia the strengthening of the connection between the state and the institution of religion, especially Christianity. The fact that a religious Christian symbol is important for the country against the backdrop of the symbol of state power on a state holiday, the visual proportionality of these monuments indicate an attempt to form a positive attitude towards the strengthening of the role of religion in the country. Thus, the importance of the joint existence of state power and the Church is emphasized. At the same time, during the Soviet era, religion was persecuted, many churches and temples were destroyed. Thanks to the installation of the monument to Vladimir the Great, the episode with the persecution of the church is erased from history. Thus, the monument to the Baptizer of Russia transforms the cultural memory.

\section{CONCLUSION}

Thus, the main role in the visual epistemology of imperial consciousness belongs to the monumental arts. In the various visual examples, we see how the imperial culture constructs the imperial image. One of the strongest genres of the visuality for the imperial images construction is the monumental sculpture. Sculptures present and shape the imperial consciousness from Symbolic Center of Empire to other territories, both inside the country and outside it, using various images, for example, using an image the same monuments in the form of postcards, pictures on the Internet and the like.

Practices of symbolic association of territories with the help of monumental statues of national history heroes can be observed both in the history of European classical empires of the 18th and 19th centuries, and in the history of empires of a new type, formed in the era of globalization. Marking territories as their own with the help of monumental art suggests that modern Russia has imperial ambitions and carries out traditional imperial cultural practices.

The reported study was funded by RFBR according to the research project № 18-311-00273.

\section{REFERENCE LIST}

Astafyeva O.N., Avanesova G.A., 2015. The development of national culture and cultural policy in the Russian Empire and the USSR: a comparative analysis. Yaroslavl Pedagogical Herald, vol. 4.

Bleichmar D., 2012. Visible Empire. Botanical expeditions and visual culture in the Hispanic Enlightenment.

Bleichmar D., 2015. The Imperial Visual Archive: Images, Evidence, and Knowledge in the Early Modern Hispanic World. Colonial Latin American Review, vol. 24.

Fedulin AA, Bagdasaryan V.E. Monumental sculpture and the struggle of ideologies: history and actual challenges. Modern problems of service and tourism. 2013. № 4. P.11-17 
Gushchyan L., Magomedova A., Mahmudova Z. Imperial symbols in the art of the Caucasus. Homeland. 2014. No. 9. P.131-133.

Saenko N.R., Shipitsin A.I., 2010. Cultural-symbolic policy in relation to urban sculpture. Questions of culturology, vol. 12.

Shcherbinina N.G. Monumental sculpture as a visual deconstruction of "Russia". Praxeme. Problems of visual semiotics. 2015. № 1 (3). Pp. 43-50.

Shumikhina M.N. Art as the conductor of political myth into life. Bulletin of the Humanities University. 2017. No. 3 (18). P.127-131.

Vishlenkova E.A., 2005. To see the empire: the city in the visual culture of Russia XVIII - the first quarter of the XIX century. Scientific notes of Kazan University, vol. 147.

Zlotnikova T.S. The imperial unconscious is the context of a person's creative self-awareness. Yaroslavl Pedagogical Bulletin. 2014. T.1. № 2. P. 213-217. 